\title{
Advice and Consent: The Role of the United States Senate in the Judicial Selection Process
}

Senator Charles McC. Mathias, Jr. $\dagger$

Among all the responsibilities of a United States Senator, none is more important than the duty to participate in the process of selecting judges and justices to serve on the federal courts. While this duty is typically discharged routinely and in some degree of obscurity, the Senate's deliberations on President Reagan's nominations to the federal bench attracted a great deal of public attention during the Ninety-Ninth Congress. The issue before the Senate in each case is never simply whether or not to confirm a particular nomination. Instead, the debate always implicates a far broader question: what is the role of the Senate in the crucial but little understood process that we refer to by the constitutional shorthand of "advice and consent"?

The Senate's duty in this sphere is extraordinary. Most other senatorial decisions are subject to revision, either by the Congress itself or by the executive branch. Statutes can be amended, budgets rewritten, appropriations deferred or rescinded. But a judicial confirmation is different.

When the framers of the Constitution decided that federal judges "shall hold their offices during good Behaviour," and may be removed only by the rarely utilized process of impeachment, they guaranteed respect for the principle of judicial independence. Their decision also meant, however, that the vote to confirm a judicial nominee must express the Senate's confidence in the nominee's ability to decide the burning legal controversies not only of

† Charles McC. Mathias, Jr., a Republican from Maryland, retired from the United States Senate in January 1987 after serving in the Congress for twenty-six years. He is now a partner in the Washington, D.C. office of the law firm of Jones, Day, Reavis, and Pogue.

Throughout his eighteen years in the Senate, Mr. Mathias was a member of the Judiciary Committee, the body with primary responsibility for reviewing nominations to the federal courts. During that period, the Committee reviewed 722 nominations to the district courts, 204 nominations to the courts of appeal, and 10 nominations to the Supreme Court that were made by 4 presidents. Mr. Mathias would like to acknowledge Steven Metalitz and Matthew Gerson, attorneys on his Judiciary Committee staff, for their assistance in the preparation of this essay. 
the day but of future decades as well. A senator serving in the 100th Congress cannot know what the legal issues of the twentyfirst century will be; they may bear little resemblance to those that currently animate the nation. We can be certain, however, that judges appointed to the federal bench during the 100th Congress will have to decide those distant controversies.

This short essay explores the meaning and implications of this weighty duty from the perspective of one who has been involved in the process. I first investigate the constitutional foundation of the duty to "advise and consent," then turn to the practical and political mechanisms that have been built on that foundation. Finally, I offer some recommendations for improvements in the current process of nominating and approving judges.

I.

An examination of the Senate's role in the process of choosing the federal judiciary should start by going to the source. The Senate's duty to "advise and consent" derives from article II, section 2 of the Constitution, which provides:

[The President] shall nominate, and by and with the Advice and Consent of the Senate, shall appoint ... Judges of the supreme Court, and all other officers of the United States, whose Appointments are not herein otherwise provided for, and which shall be established by Law.

The Constitution tells us no more than this. It does not tell the Senate how to assess a nominee to the federal bench. It imposes no job qualifications-of age, citizenship, or even admission to the bar. It does not list the intellectual or temperamental qualities the nation should demand of its judges. It offers no guidelines for acceptance or rejection. The Constitution indicates only that the appointment of federal judges is too important to be reposed in the hands of one branch alone, and that the Senate has two distinct roles: to advise the president in his selection process and to consent to-or, by implication, reject-the president's choice.

Legend has it that in the course of debating the method for appointing judges, Ben Franklin suggested that Supreme Court nominations be made by lawyers. Franklin thought that practitioners would want to eliminate their strongest competitors and, as a result, would nominate only the most able lawyers. More authoritative sources indicate that early drafts of the Constitution empowered the Senate to appoint judges. Alexander Hamilton, however, anticipated the deficiencies in that arrangement. He proposed 
that the president nominate and appoint judges and that the Senate "reject or approve" these candidates. Hamilton's proposal was ultimately accepted, but with one significant modification: the words "reject or approve" were changed to "advice and consent." This modification ensured a role for the Senate in both the nomination and confirmation of judges.

To illuminate the policy behind the terse words of article II, we may turn to the The Federalist Papers. In Federalist No. 76, Hamilton argues the case for dividing the appointment power between the president and the Senate. The president should have the power to nominate, Hamilton reasons, because "one man of discernment is better fitted to analyze and estimate the peculiar qualities adapted to particular offices, than a body of men of equal, or perhaps even of superior discernment." But Hamilton also predicted that "the necessity of ... concurrence [by the Senate] would have a powerful, though in general, a silent operation. It would be an excellent check upon a spirit of favoritism in the President, and would tend greatly to prevent the appointment of unfit characters from State prejudice, from family connection, from personal attachment, or from a view to popularity." Although Hamilton recognized that Senate rejection of a nomination probably would be a rare occurrence, he concluded that the Senate's participation was an essential part of the constitutional plan "to promote a judicious choice of men for filling the offices of the Union."

Although the Senate's power of consent has been in the spotlight recently, little attention has focused on the duty to advise on judicial nominations. The Federalist does not clearly distinguish advice from consent. Certainly, as Hamilton argues, the power to nominate is the president's alone; and while a senator is in an excellent position to know which individuals within his constituency are best qualified to be federal judges, the president obviously need not heed his "advice." But both historical tradition and the practical considerations that flow from the ultimate requirement of Senate concurrence have strengthened the role of senators in recommending nominees. In the past, senators have been able to increase the likelihood that their recommendations will be respected by extending to one another a "senatorial courtesy." The "blue slip" system has assured that a nominee rarely will be confirmed over the objection of either senator from the nominee's state. Many have argued that this arrangement, while providing political leverage to senators, does little to ensure that only the most able candidates became judges.

Senators can, however, effectively advise the president on judi- 
cial nominations in ways that do more than simply reward favors or loyalty. One such means is by establishing committees within senators' states to recommend candidates on the basis of merit. Increasingly, senators solicit the advice of panels of lawyers, academics, and community leaders before recommending to the president individuals to fill vacancies on district courts in their home states. In my experience, this system has proven excellent at minimizing the partisan complications that may engulf the nominating process, and at improving the quality of nominees. Even though the work product of any one panel varies with the quality and professionalism of its membership, these committees generally have been worthwhile and should be encouraged.

The Senate's second function, that of consenting to (or rejecting) nominees, is equally important and more visible. The Senate cannot automatically consent to the nomination without abdicating its constitutional responsibility. The Constitution gives the Senate the consent power not as a mechanical formality, but as an integral part of the structure of government. If anything, the Senate's role has become even more important in recent years as federal court rulings have had a burgeoning impact in wide-ranging areas of policy. If the Senate does not take its role seriously, it will lose its effectiveness as, in Hamilton's words, "a considerable and salutary restraint upon the conduct" of the president. And if, as the result of a breakdown in the process of advice and consent, an unwise appointment is made, the people, who have the most at stake, will know whom to blame. As Hamilton wrote in Federalist No. 77, "the executive for nominating, and the Senate for approving, would participate, though in different degrees, in the opprobrium and disgrace."

Hamilton's discussion of the appointment power is informed by an acute psychological insight that remains valid today. More than any other business of the Senate, the consideration of nominations turns on personalities as much as on policies. Hamilton gives several reasons why the Senate would be unlikely to reject a nominee. The first is based on practical politics: the president would simply make another nomination, with which the Senate might be equally, or even more, unhappy. But Hamilton gives another reason in Federalist No. 77: "as their dissent might cast a kind of stigma upon the individual rejected, and might have the appearance of a reflection upon the judgment of the chief magistrate, it is not likely that their sanction would often be refused, where there were not special and strong reasons for the refusal."

As Hamilton recognizes, the Senate's action upon a nomina- 
tion is strongly colored by how senators feel about two people. The first, of course, is the nominee. Even a senator who is convinced that a nominee is not well-suited for the bench must think twice about the stigma that rejection of the nomination may cast upon a man or woman who, in almost every case, is intelligent, hard-working, honest, and well-intentioned. At some point, of course, the concern for the individual pales in comparison with the interests of society in competent adjudication. And that point is more quickly reached as the power of federal courts increases. Yet these decisions usually are not clear-cut; one can seldom say with complete confidence that a nominee would make a bad judge.

Looming larger in the Senate's consideration of a nominee is the president of the United States. The choice he has made in nominating an individual to the federal bench is imbued with the incomparable prestige of the presidency. As Hamilton wisely predicted, rejection of a nominee is inevitably a reflection on the president's judgment. No senator easily dismisses the fact that the nominee has the president's endorsement.

However, it is not the president or the president's qualifications to which a senator must give "advice and consent." A senator is only one of 100 million voters when the choice of a president is made. In the context of judicial appointments, however, a senator is one of 100 and is obligated to pass judgment on the qualification of the president's nominee.

An independent judiciary demands that the nominee present no platform, expound no particular ideology, represent no constituency, and submit to no political litmus test. It also demands that those who nominate and appoint judges do not seek simply to affirm and perpetuate their political viewpoint in their nominations and appointments. A judge must take his seat on the bench confident that he is not expected to decide cases in any particular way because of the views of the leaders of either of the other two branches. Instead, he must emerge from the nomination process knowing that the president and Senate have confidence that he will preside with only one unalterable loyalty, to the Constitution, and with only one purpose, to assure the individual standing before him a judgment based upon the law of the land.

A president is entitled to reflect his judicial and political philosophy in his judicial nominations. If a nominee is an intelligent and capable individual, and is qualified by reason of temperament, training in the law, experience at the bar, and commitment to community service, no senator will object to the nomination simply because the nominee shares the president's political orientation. His- 
tory provides ample testimony to this fact, of which the unanimous confirmation of Justice Scalia is the most recent example. If, however, it should become apparent that an individual has been selected because of his philosophical orientation rather than his professional competence, the Senate has a duty to intervene.

A president can substantially eliminate ideology from the debate if he selects a nominee whose competence is unimpeachable. Again, Justice Scalia provides a good example: while his strong conservative views were well-known, they offered little or no obstacle to his confirmation. If the Senate were to reject a good nomination for reasons that were obviously purely ideological, public censure of its action would be forthcoming, censure that, in the words of Federalist No. 77, would be "aggravated by the consideration of their having counteracted the good intentions of the executive."

The Senate must be convinced that a nominee is impeccably competent. But competence alone is not sufficient. It is not enough that a nominee be skilled in legal argument and knowledgeable about legal doctrine, and that she be able to write clearly and forcefully. A candidate for the federal bench must, as Hamilton wrote in Federalist No. 78, "unite the requisite integrity with the requisite knowledge." The nominee also must exhibit a strength of character and a range of vision that will help her look beyond the world that exists on the day on which she is nominated. Thus, the character of a nominee is neither tangential nor irrelevant to her fitness for the bench.

\section{II.}

As the Senate embarks on its third century, its role in the judicial nomination process merits increased attention. My reflections on eighteen years as a participant in that process have led me to make a few suggestions for improvement.

First, the Senate should reassess the importance of its constitutional role with respect to judicial nomination, and should consider allocating more resources to the performance of that role. The Senate Judiciary Committee is structured primarily for the consideration of legislation. But there may be times-the NinetyNinth Congress, I believe, was one of them-when the significance of the Committee's actions on its executive calendar of nominations rivals, or even outweighs, its legislative agenda. The Committee should be confident that it is devoting enough funds, staff, and time to the consideration of a nomination. Midway though the Ninety-Ninth Congress, the Committee adopted a timetable designed to ensure that there would be adequate opportunity for a 
thorough investigation even of seemingly routine nominations, and it provided additional time for those cases meriting special attention. This salutary precedent should be continued. Unlike legislation, action on a judicial nomination processed in haste cannot be revisited and refined at leisure.

Second, the full Senate should have the opportunity to consider each nomination on a complete record. The recommendation of the Judiciary Committee no doubt will continue to be of paramount importance to other senators; but they also should have the opportunity to review the transcripts of hearings on nominations and to solicit other advice on the merits of the issue before voting. In this regard, the preparation of a written committee report, including minority views, on controversial or particularly significant nominations should be the rule, rather than the exception.

Third, the Senate should be more willing to inquire into how the nominee has come before it in the first place, and it should adapt its investigative procedures depending on the answer it receives.

A number of resources are available for such an inquiry. The Department of Justice should be asked not only to explain its general procedures for selecting nominees, including the role of senatorial advice, but also to offer its assessment of the factors that best demonstrate a particular nominee's fitness for the bench. The American Bar Association's Standing Committee on the Federal Judiciary should be encouraged to provide more detail on the evaluation of nominees referred to it, particularly in cases in which it is less than unanimous in its conclusion that a nominee is qualified. When a nominee has been recommended by a senator's advisory committee, that panel should be invited to describe its procedures and offer the reasons for its conclusions. And particularly when such a screening mechanism has not been employed, the Judiciary Committee should undertake an affirmative effort to solicit the views of the bar of the jurisdiction where the nominee will sit if confirmed, and of other reputable and representative organizations that are concerned about the composition of the federal bench.

The goal of these procedures is not to second-guess the judgment of the president in submitting the nomination to the Senate, but to ensure that the factors underlying that judgment are sufficiently disclosed to permit the Senate to make an informed and independent evaluation of the president's choice.

III.

Adoption of these procedures in a way that does not unduly 
delay or complicate the confirmation process should help the Senate improve its decisions on judicial nominations. But it would be folly to claim that procedural reforms can relieve senators of the burden of a tough decision on a controversial nomination. And the decision may often be tough indeed, requiring an adherence to principle in the face of strong partisan pressures. For when the Senate carries out its function of advice and consent, its first loyalty must be not to the political parties, nor to the president, but to the people, and to the Constitution they have established.

The paramount constitutional duty of the Senate in the process of advice and consent is to satisfy itself that the nominee before it is fully qualified, by virtue of education, experience, integrity, and character, to be granted a lifetime commission to sit in judgment upon the liberties and the legal rights of the American people. Before being confirmed for a seat on the district court, a nominee must be fully prepared to administer equal justice under the law in the way that distinguishes our legal system from that of any other country. Since judges of the courts of appeals will, in practice, sit as the court of last resort in the vast majority of federal cases, they must be judged by particularly stringent standards. And, of course, in the case of nominations to the Supreme Court, which has the ultimate authority to interpret and apply the Constitution, the Senate's scrutiny must be exacting in every respect. Only with vigorous review can the Senate carry out the role envisioned for it by the framers of the Constitution-to provide a "salutary restraint" upon executive power, by permitting the appointment to the federal bench of only those men and women who are fully qualified to serve there. 